\title{
SEXUAL FUNCTION OF Ca MAMMAE PATIENTS WHOM UNDERGOING CHEMOTHERAPY
}

\author{
Dian Nur Adkhana Sari ${ }^{1}$, Eka Oktavianto² \\ 1.2 Lecturer of Nursing Study Program STIKES Surya Global Yogyakarta \\ Corresponding e-mail: dian.adkhana@gmail.com
}

\begin{abstract}
BACKGROUND : Ca mamae is one of the first rank in cancer case every year. One of the treatment for Ca mamae is chemotherapy which has an effect of losing interest in sexuality. The purpose of this study was to identify sexual function problems of $\mathrm{Ca}$ Mamae patients whom undergoing chemotherapy.

SUBJECT AND METHODE : This is descriptive conducted with cross sectional research design through survey. The sample in this study were 31 respondents and sampling method with purposive sampling. Measurement in this study used FSFI questionnaire, to identify components of sexual desire, sexual arousal, lubrication, orgasm, satisfaction and pain. Data analyzed used SPSS program.

RESULTS : The results of this study found that $2(6.4 \%)$ respondents in normal sexual satisfaction and $29(93.5 \%)$ respondents with sexual impaired function.

CONCLUSION : The conclusion of this study is the incidence of sexual function disorders in patients with Ca mamae still being majority case.
\end{abstract}

Keywords: sexual function, ca mamae

\section{INTRODUCTION}

Breast cancer is the most majority case of cancer in the world and attacks on women. In the last decade, the number of breast cancer survivors has increased globally. The term "breast cancer" is a malignant tumor that has developed from cells in the breast. The growth of cells in the breast that is out of control, which occurs as a result of mutations, or abnormal changes, in the part of the gene responsible for regulating cell growth that maintains to stay healthy (Anna \& Maria, 2014). There are $5-10 \%$ of cancer caused by abnormalities inherited from the patient's mother or father. $85-90 \%$ of breast cancer is caused by genetic disorders that occur as a result of the aging process and lifestyle (www.breastcancer.org).

Breast cancer patients in 2012 around 1.7 million women were diagnosed with breast cancer and as many as 6.3 million women were diagnosed with breast cancer in the previous five years (Ferlay, et.al, 2012). A total of 122 / 100,000 women suffer from breast cancer and resulted in $21.5 / 100,000$ women died of breast cancer. The prevalence of breast cancer incidence in the United States in 2013 was 296,890 cases (CDC, 2014). The incidence of breast cancer reached $347,792(1.4 \%$ of the total population) in West Java occurred 6,701 cases (Indonesian Ministry of Health, 2013). 
One of the method to handling breast cancer is with chemotherapy. Chemotherapy is the administration of chemicals for the treatment of diseases. The term chemotherapy refers exclusively to the use of cytostatic drugs (Indrawati \& Maya, 2009).

Every patient has a different level of compliance. The impact of routine chemotherapy is killing cancer cells. Chemotherapy will make the progression of the disease slower and reduce complaints. Patients who do not do chemotherapy regularly will cause cancer cells spread to other healthy organs (Azwar, 2012). Side effects of chemotherapy include hair loss, weight gain, nausea, vomiting and fatigue. Chemotherapy can cause vaginal irritation and dyspareunia, changes in body image. Breast cancer sufferers are afraid of death and fear of happening rejection of partners (Erica \& Don, 2015).

Chemotherapy will cause short-term and long-term effects including sleep disorders, weight changes, bladder disorders, changes in body odor, loss of skin sensation, impaired body image, sexual function disorders, pain during sexual intercourse this will increase anxiety patients who will have an impact on depression (Lindau, et.al, 2015).

Sexuality is the most intimate aspect of a relationship, sexuality is related to emotional feelings, related to one's well-being and experience in a relationship (Walsh et.al, 2005). There are various ways done to achieve maximum sexual function in sexual activity. The inability of a person to fulfill the condition of maximum sexual function is called sexual dysfunction (Tahalele, 2018). Women who experience sexual dysfunction disorders will experience decreased sexual desire I drive, difficulty in sexual arousal, difficulty reaching orgasm and feel pain during sexual intercourse (Bason, et.al. 2010).

A woman who has a good sexual function could has a good sexual relationship and able to create sexual satisfaction (Smith.et.al. 2012). Domains of sexual function include sexual desire, sexual arousal, orgasm, satisfaction, genital mucus discharge and a sense of comfort or pain during sexual intercourse (Rosen, et.al, 2000).

One of the way to handle Ca mamae is using chemotherapy to kill cancer cells. The effects of chemotherapy are very disturbing. One of the most disruption is function of sexuality. From these problems the researcher arises the question of how sexual desire, sexual arousal, orgasm, feeling of satisfaction, genital mucus discharge and a sense of comfort when having sexual intercourse ca mamae patients whom undergoing chemotherapy. Based on this background the researchers wanted to find out how the sexual function of patients with ca mamae who underwent chemotherapy. This study is conduct to identify sexual function problems of $\mathrm{Ca}$ Mamae patients whom undergoing chemotherapy.

\section{METHODE}

The design in this study was cross sectional through surveys. The sample in this study were 31 patients with $\mathrm{Ca}$ mamae whom undergoing chemotherapy in accordance with predetermined inclusion criteria. Measuring instruments use the Female Sexual Function Index (FSFI) questionnaire to find out sexual function in which prayer in FSFI includes sexual desire, sexual arousal, orgasm, satisfaction, genital mucus discharge and discomfort or pain during sexual 
intercourse. Pe The study was conducted at a hospital in Yogyakarta. Data collection by filling out the questionnaire that has been given by researchers. All data obtained were analyzed using the SPSS program with a computer

This research was conducted an ethics test on May 6, 2018 with ethical number 210 / KEPK / SG / V / 2019 from the STIKES Surya Global Yogyakarta ethics commission.

\section{RESULTS AND DISCUSSION}

Table 1 Frequency distribution of Repondents Characteristics (Primary Data, 2019)

\begin{tabular}{lll}
\hline Characteristics & $\mathrm{n}$ & $\%$ \\
\hline Age (years old) & & \\
$25-30$ & 1 & $3,2 \%$ \\
$31-35$ & 7 & $22,5 \%$ \\
$36-40$ & 9 & $29,03 \%$ \\
$41-45$ & 14 & $45,1 \%$ \\
Level of education & & \\
Elementary school & 11 & $35,4 \%$ \\
Middle and high school & 9 & $29,03 \%$ \\
Highly education & 4 & $12,9 \%$ \\
University college & 7 & $22,5 \%$ \\
Occupation & & \\
House wife & 16 & $51,6 \%$ \\
Police/ government & 3 & $9,6 \%$ \\
Employee & 5 & $16,1 \%$ \\
Trader & 2 & $6,4 \%$ \\
Farmer & 2 & $6,4 \%$ \\
\hline
\end{tabular}

Table 1 shows that the majority of patients with ca mamae for the age group 41-45 years is 14 respondents $(45.1 \%)$, elementary school is 11 respondents $(35.4 \%)$, having children more than 2 is 16 respondents ( $51.4 \%)$.

Table 2. Description of FSFI scores of respondents Ca mamae who undergo chemotherapy (Primary Data, 2019)

\begin{tabular}{lll}
\hline Variabel & $\mathrm{N}$ & $\%$ \\
\hline Value FSFI & & \\
Disfuction sexual & 29 & $93,5 \%$ \\
Fuction sexual is good & 2 & $6,4 \%$ \\
\hline
\end{tabular}

Table 2 shows that the sexual function based on the FSFI questionnaire is considered low or experiencing sexual dysfunction if the value of the total FSFI domain is lower than 26.55 (26.55). The results of the above table calculation obtained the value of 31 respondents are 29 respondents 
(93.5\%) experienced sexual dysfunction, and there are 2 respondents (6.4\%) with good sexual function.

Table 3. Overview of Sexual Function of respondents Ca mamae who undergo chemotherapy (Primary Data, 2019)

\begin{tabular}{lccc}
\hline Domain & Mean & Median & Min - Max \\
\hline FSI & 3.11 & 3.6 & $1.2-4.80$ \\
Sexual stimulation & 2.25 & 2.1 & $0.00-6.00$ \\
Lubrication & 2.09 & 2.11 & $0.3-6$ \\
Satisfaction & 3.5 & 3.6 & $2-6$ \\
Pain & 2.09 & 2 & $0-6$ \\
\hline
\end{tabular}

From the table above, it can be seen that the average sexual function domain based on the FSFI questionnaire sequentially from the highest is the domain satisfaction $=3.5$, sexual desire $=3.11$, sexual stimulation $=2.25$, lubrication $=2.09$ and pain $=2.09$.

Ca Mamae patients whom undergoing chemotherapy in this study had an age range of 41-45 years were 14 respondents (45.1\%) as majority. Supported by research from Anggraeni (2011) that the majority of Ca mamae sufferers> 40 years old were 52 respondents $(39.7 \%)$. Chemotherapy measures taken by patients with ca mamae who are more than 40 years old will have an effect on long-term sexual disorders (Krychman \& Katz, 2012). The more person's age will affect the interest and decrease sexual relations. The presence of a disease will also affect sexual function (Afiyanti, 2011). One study by Kowalczy et al. (2019) showed a relationship between younger age and good sexual function.

Characteristics of patients with ca mamae in this study was the majority of respondents had an elementary school education of 11 respondents (35.4\%). Supported by the study of Pratiwi et al (2017) patients with ca mamae almost half of the respondents mostly elementary school educated. Research conducted by Agustini et al (2015) obtained characteristic data carried out by patients with primary education. The higher a person's education, the easier absorb information (Notoatmodjo, 2010). Knowledge is not only influenced by the level of education but also influenced by non-formal education as well as the ease of accessing information from the internet that will facilitate in getting information and adding knowledge, someone with any background is very likely to get the opportunity to increase the knowledge of ca ca especially about sexual dysfunction problems (Farhani, 2014). Characteristics of most respondents did not work and it was about 16 respondents (51.6\%). Research conductedby Rashidi \& Dashti (2015) found that the occupational characteristics of respondents were not working as much as $80 \%$. Person who does not work will have a personal time allocation of 10 hours / day the rest of childcare activities and domestic activities, this shows that the workload will have very little (Lestari, 2011). A hardwork will increase the risk of stress this will have an impact on the decline in sexual function (Indrayani \& Sofiyanti, 2016). The results of this study showed that the majority of respondents did not work but the data showed there were still many sexual dysfunctions.

Based on the results of this study showed that there were $93.5 \%$ who experienced sexual dysfunction $(<26.55)$ and the remaining $6.4 \%$ of respondents with good sexual function scores (FSFI> 26.55). Patients who did chemotherapy will be at greater risk of sexual dysfunction (Lara et al, 2012). Supported by Kowalczy et al (2019) showed that $57.1 \%$ of Ca mamae patients 
experience sexual dysfunction. Chemotherapy has an impact on sexual dysfunction and this will affect the relationship with the patient's partner. A good sexual function will reduce anxiety and increase physical and emotional satisfaction in this relationship will improve the quality of sexual life with a partner. The occurrence of sexual dysfunction will have an impact such as depression, or it can occured because suffering from the disease and caused sexual problems.

Sexual problems have an important role in a relationship, the effects of chemotherapy will cause sexuality problems, one of which is vaginal dryness and an effect on sexual desire and arousal, this will have an impact on disputes in marriage (Rezaei, 2016). Chemotherapy action that affects complaints of sexuality is characterized by decreased libido and will result in sexual dysfunction that will affect life and impact on stress (Krychman \& Katz, 2012).

The domain of sexual function in this study was the part that experienced the most problems in the domain of satisfaction. Sexual satisfaction is related to a history of the usual actions of chemotherapy will result in hot and dry sensation in the vaginal area (Zeng \& Loke, 2012). Sexual satisfaction can increase if accompanied by a quality communication relationship with a partner (Stephenson \& Meston, 2010). Patients whom undergoing chemotherapy will feel pain and this will interfere with sexual satisfaction (Guerin \& Hill, 2010)

\section{CONCLUSION AND RECOMMENDATION}

Based on sexual function of ca mamae patients whom undergoing chemotherapy found that 2 respondents $(6.4 \%)$ in the sexual function category and 29 respondents $(93.5 \%)$ in the sexual dysfunction category. The results of the sexual function domain based on the FSFI questionnaire sequentially from the highest are the satisfaction domain $=3.5$, sexual desire $=3.11$, sexual stimulation $=2.25$, lubrication $=2.09$ and pain $=2.09$.

The results of this study are expected for health workers to provide health education related to the problem of sexual function of patients with ca mamae who are undergoing chemotherapy. The hospital's policy is needed to provide training to nurses in special programs in health promotion to increase knowledge in education, counseling and interventions related to sexual function, not only patients but husband and wife.

It is hoped that there will be follow-up research related to the sexual function of husband and wife and household harmony in ca mamae patients undergoing chemotherapy.

\section{REFERRENCE}

Afiyanti. 2011. Perubahan Keluhan Fisik dan Psikologis pada Perempuan pascaterapi Kanker Serviks setelah Intervensi Keperawatan. Jurnal Ners. Vol 6, No 1 Anggraeni,D,R. 2011. Hubungan Antara Faktor Usia dengan Angka Kejadian Carsinoma Mamae di

RSUD dr. Moewardi Surakarta. Fakultas Kedokteran Universitas Muhammadiyah Yogyakarta 
Agustini, Surahman\&Abdulah. 2017. Kualitas Hidup Pasien Kanker Payudara dengan Terapi Kombinasi Fluorouracil, Doxorubicin dan Cyclofosfamide. Jurnal farmasi Klinik Indonesia. Vol 4 No

Anna\&Maria. 2014. Nursing Intervensions In Female Breast Cancer Patients.. Narrative Literature Review. Bacelor's Thesis Nursing Program in Health Care Registered Nurse (AMK)

Azwar, B. 2012. Kemoterapi. Jakarta: Dian Rakyat

Bassoon, R, Wierman, M.E., Van Lankveld, J.,\& Brotto, L. 2010 Summaru of the recommendations on sexual dysfunction in women. The Journal of sexual medicine, 7(1pt2), 314-326

Brody S, Costa RM. Satisfaction (sexual, life, relationship, and mental health) is associated directly with penile-vaginal inter- course, but inversely with other sexual behavior frequencies. J Sex Med 2009;6:1947-54.

CDC. Cancer among women. CDC [Internet]. 2014 [updated 2014 Sep 2, cited 2014 Sep 5]. Available from: http://www.cdc.gov/ cancer/dcpc/data/women.htm

Erica\&Don . 2015. Breast cancer and sexual function. Journal Translational Andrology and Urology. doi: 10.3978/j.issn.2223-4683.2014.12.04

Farhani, F. 2014. Hubungan Tingkat Pendidikan dengan pengetahuan Ibu Hamil Tentang Hubungan Seksual Saat Kehamilan di wilayah Sukabumi Utara. Program Studi IImu Keperawatan Fakultas Kedokteran dan IImu Kesehatan Universitas Islam Negeri Syarif Hidayatullah

Ferlay J, Soerjomataram I, Ervik M, Dikshit R, Eser S, Mathers C, et al. 2012 Cancer incidence and mortality worldwide: sources, methods and major patterns in Globocan. IARC CancerBase No. 11. Lyon, France: International Agency for Research on Cancer

Guérin S, Hill C. [Cancer epidemiology in France in 2010, comparison with the USA]. Bull Cancer (Paris). 2010;97:47-PubMed | Google Scholar

Indrayani\&Sofiyanti. 2016. Faktor-faktor yang Berhubungan Dengan Penurunan Hubungan Seksual pada Ibu Menopause di Desa Kadu Madang Kecamatan Cimanuk Kabupaten Pandeglang Provinsi banten th 2016. Jurnal IImu dan Budaya. Vol 40, No 55 Maret 2017

Indrawati\&Maya. 2009. Bahaya kanker bagi Wanita dan Pria: Pengenalan, Penanganan dan Pencegahan Kanker. Jakarta:AV Publisher

Kementrian Kesehatan RI. (2013). Riset Kesehatan Dasar Riskesdas 2013. Jakarta: Badan Penelitian dan Pengembangan Kesehatan.

Kowalczyk, R. Nowosielski, K, Cendrych,I. 2019. Factors affecting sexual function and body image of early-stage breast cancer survivors in Poland: a short-term observation. Elsevier

Krychman\&Katz. 2012. Breast Cancer and Sexuality: Multi-modal Treatment Options (CME). The Journal of sexual medicine. Elsevier

Lara LA, de Andrade JM, Consolo FD, Romao AP. Women's poorer satisfaction with their sex lives following gynecologic cancer treatment. Clin J Oncol Nurs.2012 Jun 1;16(3):273-7. PubMed | Google Scholar

Lestari, E,P. 2011. Beban Kerja Ibu, Dukungan Sosial, Serta Hubungannya dengan Alokasi Waktu Pengasuhan di Daerah Rawan Pangan Kabupaten Banjarnegara, Provinsi Jateng. Departemen IImu Keluarga dan Konsumen Fakultas Ekologi Manusia Institut Pertanian Bogor

Lindau, S.T, Abramsohn,E.M, Matthews A.C. 2015. American Journal of Obstetric Vol 213. Elsevier 
Notoatmodjo, Sukidjo. 2010. IImu Perilaku Kesehatan. Jakarta: Rineka Cipta

Pratiwi, Widianti\&Solehati. 2017. Gambaran Faktor-Faktor yang Berhubungan dengan Kecemasan Pasien Kanker Payudara dalam Menjalani Kemoterapi. Jurnal Pendidikan Keperawatan.

Rashidi,S\&Dashti, F. 2015. Sexual Behaviour Pattern and Related Factors in Women with Breast Cancer in Iran. Global Journal of Health Science. V.8(7)

Rezaei, M, Elyasi, F, Janbabai, G, Moosazadeh,M\&Hamzehgardeshi, Z. 2016. Factor Influencing Body Image in Women With Breast a Cancer: A Comprehensive Literature Review. Iran Red Crescent Med J

Rosen, R., Brown, C., Heiman. J.,Leiblum, S., Meston, C.,Shabsigh, R., Ferquson, D., D'Aqostino, R.Jr. 2000. The Female Sexual Function Index (FSFI): A Multidimensional Self-Report Instrument for the Assessment of Female Sexual Function. Journal of Sex and Marital Therapy, 26:191-208

Smith, A.M.A., Patrick, K., Heywood, W., Pitts, M.K., Richters, J., Shelley, J.M., \&Ryall,R (2012). Body mass index, sexual difficulties and sexual satisfaction among people in regular hsseterosexual 